\title{
Developing Competencies of Medical Students Using Group Discussion as TL Method
}

\author{
Dr. Sharmila S. Raut ${ }^{1}$, Dr. Mungal Shreechakradhar U. ${ }^{2}$, Dr. S. R. More, \\ Dr. V. S. Rathod ${ }^{4}$, Dr. V. M. Gujar ${ }^{5}$, Dr. V. Nardele ${ }^{6}$, Dr. V. Rajhans ${ }^{7}$, \\ Dr. C. Kale ${ }^{8}$ \\ ${ }^{1}$ (Professor \& Head, Department of Microbiology, Dr. Shankarrao Chavan Government Medical College, \\ Nanded. Maharashtra. India.) \\ ${ }^{2}$ (Asst. Professor, Department of Physiology, Dr. Shankarrao Chavan Government Medical College, Nanded. \\ Maharashtra. India.) \\ 3 to 8(Asso. Professor, Asst. Professor, Postgraduate students, Department of Microbiology, \\ Dr. Shankarrao Chavan Government Medical College, Nanded. Maharashtra. India.)
}

\begin{abstract}
In the classroom environment discussion is one of the best ways of promoting conductive learning and convenient teaching situations. It refers to the method of instructions which gives pupils an opportunity to express their views or opinions orally on certain issues. It also involves sharing of ideas and experiences, solving problems and promoting tolerance with understanding.

This study is undertaken as a pilot project to introduce group discussion as an innovative T-L method in curriculum of Microbiology at Government Medical College, Nanded. In this study, sessions of group discussions were planned for II ${ }^{\text {nd }}$ MBBS students. Pretest and post-test were conducted before and after the session. Feedback was taken from the students.

Result:There was significant increase in scores of students before and after Group Discussion session. Most of the students opined that groups work better as a teaching learning method, also there was no confusion during group discussion regarding the topic. There was huge agreement on the opinion that group discussion helped students to remember the topic and to improve their communication skills. They reported that group discussion is student friendly method of teaching-learning process.

Conclusion:Group discussion not only helps to understand and remember the subject better but also develops essential qualities of a successful medical professional.

Keywords: Group discussion, teaching learning method, small group teaching.
\end{abstract}

\section{INTRODUCTION}

Teaching learning is a continuously changing process. Over the years, various studies convinced that traditional discipline based curriculum in medical education is dehumanizing and demotivating [1]. During recent years, many researchers in medical education promoted competency based curriculum which emphasizes small group teaching. Small group teaching has been the highlight of a revolution in the medical education over the last 40 years [2]. Small groups can take on a variety of different tasks, including problem solving, role play, discussion, brainstorming, debate, workshops and presentations [3].Among these we choose group discussion as teaching- learning method for small group. Small group discussions provide opportunities for students to ask questions, opinions, consider alternatives, and express themselves to peers. Research has demonstrated that group discussion promotes greater synthesis and retention of materials and more creative problem solving [4].

\section{Context of Study:}

In the classroom environment discussion is one of the best ways of promoting conductive learning and convenient teaching situations. It refers to the method of instructions which gives pupils an opportunity to express their views or opinions orally on certain issues. It also involves sharing of ideas and experiences, solving problems and promoting tolerance with understanding [5].

Although many studies have been conducted all over the world regarding different forms of small group teaching, very little data is available on use of group discussion as a tool of small group teaching. So this study is undertaken as a pilot project to introduce group discussion as an innovative T-L method in curriculum of Microbiology at Dr. Shankarrao Chavan Government Medical College, Nanded to increase competency of forthcoming health professionals in areas of communication skills, analytical decision making, presenting skill, problem solving, teamwork and knowledge. 


\section{MATERIAL AND MethodS}

This study was conducted in Department of Microbiology at Dr. Shankarrao Chavan Government Medical College, Nanded, Maharashtra. Participants for this study were Second MBBS students during Academic Year 2013-14. Written consents of students and faculties were taken. Institutional ethical committee approval was taken prior to the study.

Four sessions of group discussions were planned for $\mathrm{II}^{\text {nd }}$ MBBS students for Bacteriology Module. Before starting the actual project work students as well as faculties were given an orientation seminar on group discussion and group dynamics. Whole batch is divided into four groups having twelve students in each with one facilitator allotted to each group. Ground rules of group discussion were laid down by interaction with the students. Pretest and post -test were conducted before and after the session. Feedback was taken from the students by providing pretested and validated questionnaires (Annexure 1). Feedback included constructed response with open ended question and selected response with Likert scale and overall Global Rating Scale.

\section{Observation And Results}

47 students participated and gave the feedback.

Data obtained was analyzed using SPSS 21.00 Version

- $\quad$ Paired T Test was applied for comparing pre - test and post - test scores of students.

- Descriptive analysis using bar diagrams and pie charts was done for the feedback questions.

Table - 1

\begin{tabular}{|c|c|c|c|c|c|}
\hline \multicolumn{7}{|c|}{ Paired t test analysis for comparison between Pre Test score and Post Test score } \\
\hline & Mean & $\mathrm{N}$ & Std. Deviation & Std. Error Mean & P value \\
\hline $\begin{array}{c}\text { Pre } \\
\text { test score }\end{array}$ & 5.915 & 47 & 1.6917 & 0.2468 & $<0.0001$ \\
\hline Post test score & 8.277 & 47 & 1.3941 & 0.2034 & \\
\hline
\end{tabular}

Comparison of scores before and after Group discussion session

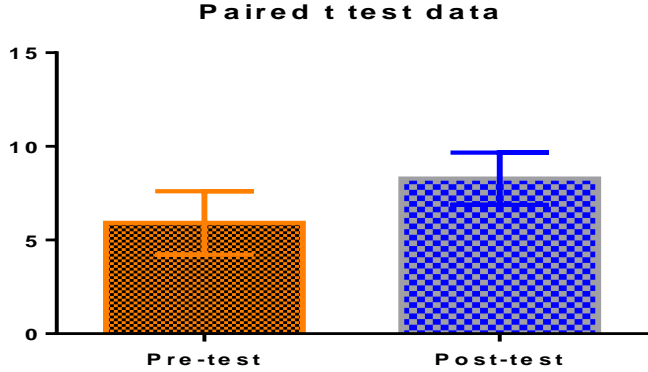

Inference: There was significant difference in scores of students before and after Group Discussion session.

Students' perspectives on different aspects of group discussion: Table 2

\begin{tabular}{|c|l|c|c|c|c|c|}
\hline & \multicolumn{1}{|c|}{ Item } & $\begin{array}{l}\text { No. of students } \\
\text { said Strongly } \\
\text { Disagree }\end{array}$ & $\begin{array}{l}\text { No. of students } \\
\text { said Disagree }\end{array}$ & $\begin{array}{l}\text { No. of } \\
\text { students said } \\
\text { Neutral }\end{array}$ & $\begin{array}{l}\text { No. of students } \\
\text { said Agree }\end{array}$ & $\begin{array}{l}\text { No. of students } \\
\text { said strongly } \\
\text { agree }\end{array}$ \\
\hline 1 & $\begin{array}{l}\text { I feel comfortable } \\
\text { speaking in this class }\end{array}$ & $1(2.12 \%)$ & $4(8.51 \%)$ & $5(10.63 \%)$ & $25(53.19 \%)$ & $12(25.53 \%)$ \\
\hline 2 & $\begin{array}{l}\text { I enjoyed participating } \\
\text { in discussion }\end{array}$ & $1(2.12 \%)$ & $1(2.12 \%)$ & $2(4.25 \%)$ & $17(36.17 \%)$ & $26(55.31 \%)$ \\
\hline 3 & $\begin{array}{l}\text { I find that groups } \\
\text { work better as person } \\
\text { has an assigned role in } \\
\text { the group }\end{array}$ & $1(2.12 \%)$ & $2(4.25 \%)$ & $3(6.38 \%)$ & $20(42.5 \%)$ & $21(44.68 \%)$ \\
\hline 4 & $\begin{array}{l}\text { I find that working in } \\
\text { group confuses me }\end{array}$ & $15(31.91 \%)$ & $18(38.29 \%)$ & $7(14.89 \%)$ & $5(10.63 \%)$ & $2(4.25 \%)$ \\
\hline 5 & $\begin{array}{l}\text { This method helped } \\
\text { me to remember } \\
\text { contents of topic }\end{array}$ & $1(2.12 \%)$ & $1(2.12 \%)$ & & $21(44.68 \%)$ & $24(51.06 \%)$ \\
\hline 6 & $\begin{array}{l}\text { This method will } \\
\text { improve } \\
\text { communication skill }\end{array}$ & $1(2.12 \%)$ & & & $16(34.04 \%)$ & $30(63.8 \%)$ \\
\hline 7 & $\begin{array}{l}\text { I find that new method } \\
\text { is student friendly }\end{array}$ & $1(2.12 \%)$ & & $2(4.25 \%)$ & $21(44.68 \%)$ & $23(48.93 \%)$ \\
\hline
\end{tabular}


Out of total 47 students participated in group discussion $78.72 \%$ (37) were comfortable to speak in class and $91.48 \%$ (43) enjoyed the activity. $87.18 \%$ (41) students opined that groups work better as a teaching learning method. $70.2 \%$ (33) students reported that there were no confusions during group discussion regarding the topic. There was huge agreement $(95.74 \%)$ on the opinion that group discussion helped students to remember the contents of the topic. Majority of students i.e. $97.84 \%$ (46) agreed that group discussion had helped to improve their communication skills. $93.61 \%$ (44) students agreed that group discussion is student friendly method of teaching-learning process.

In response to open ended questions most of the students suggested that they should be given sufficient time at least 4-5 days for preparation of the topic of discussion.

\section{Discussion:}

Kelly M (1993) reported that small groups can be an effective learning situation in which students learn both through instructions from their teachers and from interaction with each other. The group dicussion also provides opportunities for individuals to speak in front of others and to receive feedback from teachers and peers [6]. Our findings were concordant with Kelly's study. Our study found that as group discussion increases active participation of students, it makes it more student friendly than traditional teaching methods. Also it gives fair chance to express their opinion, to learn on their own and to exchange their ideas. Similar findings were reported by Dr.Shahida Sajjad (2011 ) [7]. David Jacques (2003) [8] pointed out some problems in group discussion methods like:

1. The teacher gives a lecture rather than conducting a dialogue

2. The teacher talks too much

3. Students cannot be encouraged to talk except with difficulty; they will not talk to each other, but will only respond to questions from the tutor

4. Students do not prepare for the sessions

5. One student dominates or blocks the discussion

6. The students want to be given the solutions to problems rather than discuss them

We did not found any above mentioned problems in our study. Prior orientation seminar regarding group discussion and group dynamics perhaps would have helped in resolving the above mentioned issues.

\section{Conclusion:}

Group discussion not only helps to understand and remember the subject better but also develops competencies of a successful medical professional. Well structured group discussion can inculcate competencies like openness, networking and proactive communication. The value of effective group management in professional development and lifelong learning cannot be underestimated.

\section{References:}

[1] Laeora Berkson; Problem based learning: Have the expectations been met? Academic Medicine; 68,Number 10;October Supplement 1993.

[2] Euliano TY, Small group teaching: Clinical correlation with a human patient simulator Adv Physiol Educ 2001; 25:36-43.

[3] An Environmental Scan of Best Practices in Public Health Undergraduate Medical Education; REPORT 5: STRENGTHS, WEAKNESSES AND APPLICABILITY OF TEACHING METHODS - MARCH 2009

[4] Davis B. Tools for Teaching. San Francisco CA: Jossey-Bass Publishers; 1993

[5] ; discussion method of teaching And learning http//zvavanhuchopper.blogpost.in/2010/10/discussion - method- of - teaching And.html

[6] Kelly, M. \& Stafford, K. Managing Small Group Discussion (Workshop Series No. 9). City Polytechnic of Hong Kong, Professional Development Unit (now City University of Hong Kong, Centre for the Enhancement of Learning and Teaching); 1993.

[7] Sajjad, S. S. Effective teaching methods at higher education level. Retrieved from http://www.wfate.org/papers/Research_paper_Teaching_methods.pdf ; 2011

[8] David Jacques. Teaching small groups; BMJ. 2003 March 1; 326(7387): 492-494.

\section{STUDENTS FEEDBACK QUESTIONNAIRE}

Name (OPTIONAL):

Teaching method : small group discussion

Dear students,

This feedback questionnaire has been designed to assess effectiveness of small group discussion .Please indicate your level of agreement/disagreement with following statements by writing the number that best describe your opinion 
(PLEASE NOTE:-5-Strongly agree,1-Strongly disagree)

\begin{tabular}{|l|l|l|l|l|l|l|}
\hline $\begin{array}{l}\text { Sr } \\
\text { no }\end{array}$ & statements & $\begin{array}{l}\text { Strongly } \\
\text { Disagree }\end{array}$ & Disagree & Neutral & Agree & $\begin{array}{l}\text { Strongly } \\
\text { agree }\end{array}$ \\
\hline 1. & $\begin{array}{l}\text { I feel comfortable speaking in this } \\
\text { class }\end{array}$ & & & & & \\
\hline 2. & $\begin{array}{l}\text { I enjoyed participating in } \\
\text { discussion }\end{array}$ & & & & & \\
\hline 3. & $\begin{array}{l}\text { I find that groups work better as } \\
\text { person has an assigned role in the } \\
\text { group }\end{array}$ & & & & & \\
\hline 4. & $\begin{array}{l}\text { I find that working in group } \\
\text { confuses me }\end{array}$ & & & & & \\
\hline 5. & $\begin{array}{l}\text { This method helped me to } \\
\text { remember contents of topic }\end{array}$ & & & & & \\
\hline 6. & $\begin{array}{l}\text { This method will improve } \\
\text { communication skill }\end{array}$ & & & & & \\
\hline 7. & $\begin{array}{l}\text { I find that new method is student } \\
\text { friendly }\end{array}$ & & & & & \\
\hline
\end{tabular}

PART -II

Q-1. What impact did the teaching method have on you?

Q-2 . What suggestions do you have to improve this teaching method? 